\title{
One-step purification of two novel thermotolerant $\beta$-1,4-glucosidases from a newly isolated strain of Fusarium chlamydosporum HML278 and their characterization
}

\author{
Yongling Qin ${ }^{1,2^{*}+} \odot$, Qiqian $\mathrm{Li}^{1,2+}$, Fengfeng Luo ${ }^{1,2+}$, Yue Fu ${ }^{1,2}$ and Haiyan $\mathrm{He}^{1,2^{*}}$
}

\begin{abstract}
A newly identified cellulase-producing Fusarium chlamydosporum HML278 was cultivated under solid-state fermentation of sugarcane bagasse, and two new $\beta$-glucosides enzymes (BG FH1, BG FH2) were recovered from fermentation solution by modified non-denaturing active gel electrophoresis and gel filtration chromatography. SDS-PAGE analysis showed that the molecular weight of BG FH1 and BG FH2 was $93 \mathrm{kDa}$ and $52 \mathrm{kDa}$, respectively, and the enzyme activity was $5.6 \mathrm{U} / \mathrm{mg}$ and $11.5 \mathrm{U} / \mathrm{mg}$, respectively. The optimal reaction temperature of the enzymes was $60{ }^{\circ} \mathrm{C}$, and the enzymes were stable with a temperature lower than $70{ }^{\circ} \mathrm{C}$. The optimal pH of the purified enzymes was 6.0 , and the enzymes were stable between $\mathrm{pH} 4-10 . K_{\mathrm{m}}$ and $V_{\text {max }}$ values were $2.76 \mathrm{mg} / \mathrm{mL}$ and $20.6 \mathrm{U} / \mathrm{mg}$ for pNPG, respectively. Thin-layer chromatography and high-performance liquid chromatography analysis showed that BG FH1 and BG FH2 had hydrolysis activity toward cellobiose and could hydrolyze cellobiose into glucose. In addition, both enzymes exhibited transglycoside activity, which could use glucose to synthesize cellobiose and cellotriose, and preferentially synthesize alcohol. In conclusion, our study demonstrated that F. chlamydosporum HML278 produces heat-resistant $\beta$-glucosidases with both hydrolytic activity and transglycosidic activity, and these $\beta$-glucosidases have potential application in bioethanol and papermaking industries.
\end{abstract}

Keywords: Fusarium chlamydosporum HML278, $\beta$-glucosidase, purification, heat-resistant, transglycosidic activity

\section{Key points}

- Two new $\beta$-glucosides enzymes of Fusarium chlamydosporum HML278 were purified.

- The enzymes were stable under $70{ }^{\circ} \mathrm{C}$ and exhibited transglycoside activity.

- The enzymes have potential application in bioethanol and papermaking industries.

\footnotetext{
*Correspondence: qin0718@163.com; hhy_912@163.com

${ }^{\dagger}$ Yongling Qin, Qiqian Li and Fengfeng Luo contributed equally to this work

${ }^{2}$ Guangxi Colleges Universities Key Laboratory of Exploitation

and Utilization of Microbial and Botanical Resources, 546300 Yizhou,

China

Full list of author information is available at the end of the article
}

\section{Introduction}

Lignocellulose is a linear polysaccharide linked by $D$-glucose via $\beta$-(1,4)-glycosidic bonds, and is the most abundant renewable resource on earth (Zhang et al. 2010; Kovacs et al. 2009; Sánchez and Cardona 2008). Lignocellulose can eventually be degraded into glucose under the synergy of the cellulase system: endoglucanase (EC 3.2.1.4) randomly acts on the noncrystalline region inside the cellulose molecule to produce glucose and short fiber oligosaccharides sugar; Exoglucanase (EC 3.2.1.91) hydrolyzes $\beta$-1,4-glycosidic bonds from outside to inside along the non-reducing end of cellulose to release cellooligosaccharides, cellobiose or glucose; $\beta$-glucosidase (EC 3.2 0.1.21) hydrolyzes cellobiose or other soluble cellobiose and 
cellooligosaccharides into glucose (Gomes et al. 2018; Fan et al. 2016; Arantes and Saddler 2010 ).

$\beta$-glucosidase plays an important role in the hydrolysis of cellulose. The intermediate products of cellulose hydrolysis, such as cellobiose, cellooligosaccharides, have a strong inhibitory activity on the activity of exoglucanase and endoglucanase. $\beta$-glucosidase hydrolyzes cellobiose and cellooligosaccharides to produce glucose, reducing the inhibitory effect of these intermediate products on exoglucanase and endoglucanase, thus improve the saccharification rate of cellulose enzymes (Gomes et al. 2018; Kamila et al. 2016; Chauve et al. 2010; Ikeda et al. 2006; Tanaka et al. 2006; Wen et al. 2005).

$\beta$-glucosidase is an important industrial enzyme that has been used in many bioprocesses, including the processing of biofuels, paper industry, textile industry, waste, and food (Pei et al. 2012; Tian et al. 2010; Bayer et al. 2008; Han and Chen 2008; Rubin 2008; Villena et al. 2007; Zaldivar et al. 2001).

Thermophilic fungi can produce a variety of hydrolytic enzymes that hydrolyze cellulosic substances. These enzymes are produced in high yield and exhibit good catalytic performance stability, and are a promising industrial enzyme. (Zhang et al. 2014; Haven and Jørgensen 2013; Prawitwong et al. 2013; Pei et al. 2012).

Screening of strains producing ezymes with high $\beta$-glucosidase activity is very important in industry for the comprehensive utilization of cellulose resources and other application (Miettinen-Oinonen et al. 2004; Saloheimo et al. 1997). Xylanase, endoglucanase, and other cellulose hydrolyzing enzymes produced from Fusarium sp. have high cellulose degradation activity, and these enzymes exhibited synergistic effect on of cellulose into ethanol (Gómez-Gómez et al. 2001; Kumar et al. 1991).

In our previous study, a heat-resistant cellulase-producing Fusarium chlamydosporum strain HML278 was screened from the virgin forest samples in Guangxi, China. This strain was shown to produce and secrete three major enzyme components of cellulase system, including endoglucanase, microcrystalline cellulose, and $\beta$-glucosidase and xylanase (Qin et al. 2010). In this study, two new $\beta$-glucosidases with hydrolytic and transglycosidic activities from F. chlamydosporum HML278 were rapidly isolated and purified by using improved non-denaturing active gel electrophoresis combined with gel filtration chromatography. The optimal reaction temperature of the enzymes was $60{ }^{\circ} \mathrm{C}$, and the enzymes were stable below $70{ }^{\circ} \mathrm{C}$. The new identified enzymes may have great potential applications in bioethanol and papermaking industries.

\section{Materials and methods}

\section{Strain}

The cellulase-producing F. chlamydosporum HML 278 strainwas used in this study. F. chlamydosporum HML 278 was originally isolated from the soil beneath the rotten wood in Mulun Forestry Center, Huanjiang County, Guangxi, China (Qin et al. 2010) and deposited in the Chinese Center for Type Culture Collection (Accession No. CCTCC AF 2020006).

\section{Production of cellulase by solid-state fermentation and enzymatic activity test}

Fusarium chlamydosporum HML278 was maintained on PDA medium at $4{ }^{\circ} \mathrm{C}$ in Guangxi Colleges Universities Key Laboratary of Exploitation and Utilization of Microbial and Botanical Resources.

Production of cellulase by solid-state fermentation: the screened cellulase-producing strain grown on PDA slant was washed off with $10 \mathrm{~mL}$ of physiological saline to make a spore solution, and $10^{7}$ spores were transferred to the solid medium for second round of screening for cellulase. To make the solid medium, $6 \mathrm{~g}$ bagasse, $4 \mathrm{~g}$ bran, and $30 \mathrm{ml}$ Mandels nutrient solution (Kwon et al. 1994) were mixed in $500 \mathrm{ml}$ erlenmeyer flask. The flask was flipped twice a day, and the strain was grown for 4 days at $30{ }^{\circ} \mathrm{C} .200 \mathrm{~mL}$ of sterile $\mathrm{ddH}_{2} \mathrm{O}$ was added to the culture, and was further leached at $40{ }^{\circ} \mathrm{C}$ in a constant temperature water bath for 1 hour. The culture was filtered with four layers of gauze, and centrifuged at $6000 \mathrm{r} / \mathrm{min}$ for $10 \mathrm{~min}$. The supernatant containing crude enzymes was collected and stored at $4{ }^{\circ} \mathrm{C}$ until use (Qin et al. 2010).

Detection of $\beta$-Glucosidase enzyme activity: $0.02 \mathrm{M}$ citric acid-sodium citrate buffer solution $(\mathrm{pH} 4.8)$ was used to prepare 1\% salicin (Fluka Chemical Corp, USA) solution substrate. $0.05 \mathrm{~mL}$ of enzyme solution with appropriate concentration was mixed with $1 \mathrm{~mL}$ of $1 \%$ salicin solution, and the reaction was carried out at $60{ }^{\circ} \mathrm{C}$ for $30 \mathrm{~min} .3 \mathrm{~mL}$ of DNS reagent was added to stop the reaction. The reaction solution was boiled for $6 \mathrm{~min}$, followed by incubating at cold water bath. The absorbance was measured at $540 \mathrm{~nm}$. The amount of enzyme that produces $1 \mu \mathrm{mol}$ of glucose per minute was defined as 1 unit of enzyme activity (U) (Shoemaker and Brown 1978).

\section{Rapid detection of $\beta$-glucosidase enzyme activity}

The plate used for rapid detection of $\beta$-glucosidase enzyme activity (Kwon et al. 1994) was made with following components: ferric chloride $0.03 \%$, aescin $0.1 \%$, agar $1.5 \%$.

\section{Detection of soluble total protein}

The protein concentration was measured at $595 \mathrm{~nm}$ withthe Bradford method (Bradford 1976) by using a 
Bradford Protein Assay Kit (Beyotime Institute of Biotechnology, China).

\section{Purification of $\beta$-glucosidase}

All purification steps were performed at $4{ }^{\circ} \mathrm{C}$.

Active recovery of non-denaturing gel electrophoresis: The non-denaturing gel consisting of $8 \%$ separation gel and $4 \%$ stacking gel was run at $50 \mathrm{~V}$ constant voltage at $4{ }^{\circ} \mathrm{C}$. After electrophoresis, the activity of $\beta$-glucosidase in the gel was detected by staining of gel with specific substrate (Kwon et al. 1994) containing $0.03 \% \mathrm{FeCl}_{3}$ and $0.1 \%$ aescin. After staining for $1 \mathrm{~min}$ at $30^{\circ} \mathrm{C}$, the gel was immediately rinsed with distilled water to stop the reaction. The active protein band with black precipitation was cut off, and grinded in a pre-cooled mortar. The sample was leached with citric acid-citrate buffer $(20 \mathrm{mM}, \mathrm{pH}$ 4.8) at $4{ }^{\circ} \mathrm{C}$ for $12 \mathrm{~h}$, and centrifuged at $4000 \mathrm{r} / \mathrm{min}$ for 20 min in a $5000 \mathrm{Da}$ ultrafiltration tube for concentration and desalting.

The enzyme was further purified by HiPrep 16/60 Sephacryl S-200 h $\backslash$ High Resolution gel filtration chromatography column, using a BioLogic DuoFlow Pathfinder 80 purifier system (pressure $73 \mathrm{psi}$ ). The enzyme was eluted by using elution buffer containing $0.05 \mathrm{~mol} / \mathrm{L}$ PBS and $0.15 \mathrm{~mol} / \mathrm{L} \mathrm{NaCl}(\mathrm{pH} 7.2)$ at the flow rate of $1 \mathrm{~mL} /$ min. The enzyme activity of the purified protein was detected referring to the enzyme activity rapid detection plate of $\beta$-glucosidase, and the protein purity was detected by using SDS-PAGE.

\section{SDS-polyacrylamide gel electrophoresis(SDS-PAGE)}

The enzyme solutions were subjected to $12 \%$ SDS-polyacrylamide gel electrophoresis, and the gel was stained with Coomassie Brilliant Blue R250. The molecular weight of purified proteins was assessed by comparing the relative mobility of purified protein with low molecular weight standard protein (Laemmli 1970).

\section{Zymogram analysis of purified enzyme}

The collected enzyme solution from HML278 was subjected to non-denaturing protein gel electrophoresis with $\mathrm{pH} 8.3$ electrophoresis buffer at $4{ }^{\circ} \mathrm{C}$ by using $50 \mathrm{~V}$ constant voltage. The separation gel and stacking gel was made by $8 \%$ acrylamide and $4 \%$ acrylamide, respectively. After the electrophoresis, the acrylamide separation gel was cut and partly stained with silver, and the other part was stained with specific substrates of different cellulases.

To analyze the activity of $\beta$-glucosidase from cut gel, the gel was active stained with staining solution containing $0.1 \%$ escin (Sigma) and $0.03 \%$ ferric chloride (Sigma) for 5 minutes at $30{ }^{\circ} \mathrm{C}$. The protein with $\beta$-glucosidase activity will catalyze the substrate to produce a yellowblack product (Kwon et al. 1994).
Analysis on the hydrolysis activity of purified $\beta$-glucosidase Experiments for analyzing HML0366 $\beta$-glucosidase enzyme hydrolysis activity and transglycoside-mediated synthesis of gentiobiose.

$\beta$-glucosidase hydrolysis assay: $10 \mathrm{~mL}$ of $1 \%(\mathrm{~m} / \mathrm{v})$ cellobiose dissolved in citrate buffer (50 mM, pH 4.8) was used as a substrate, and $2 \mathrm{~mL}$ of enzyme solution was added to react at $30^{\circ} \mathrm{C}$ for $30 \mathrm{~min}$.

High performance liquid chromatography (HPLC) analysis of sugar components: The system utilized a refractive index detector and Hanbang amino column $(250 \mathrm{~mm} \times 4.6 \mathrm{~mm}, 5 \mu \mathrm{m}$, (Hanbon Sci. \& Tech. Lichospher NH2, China). $40{ }^{\circ} \mathrm{C}$; mobile phase: acetonitrile/ Water $(4: 1, \mathrm{v} / \mathrm{v})$; flow rate: $1 \mathrm{~mL} / \mathrm{min}$; injection volume: $5 \mu \mathrm{L}$.

TLC method for detecting sugar components (Jo et al. 2003): Silica thin-layer chromatography detection was utilized. Expanding agent: n-butanol: ethyl acetate: ammonia: water $=6: 3: 3: 1(\mathrm{v} / \mathrm{v})$. Developer: A: $1 \mathrm{~g}$ aniline $+25 \mathrm{~mL}$ acetone, $\mathrm{B}: 1 \mathrm{~mL}$ dianiline $+25 \mathrm{~mL}$ acetone. After mixing $\mathrm{A}$ and $\mathrm{B}, 5 \mathrm{~mL} \mathrm{85 \%}$ phosphoric acid was added and mixed well. After the chromatography, the plate was blown dry and color developer was sprayed, and dried at $120{ }^{\circ} \mathrm{C}$ for 10 minutes to develop color.

Cellobiose was dissolved in $20 \mathrm{mM}$ citrate buffer ( $\mathrm{pH}$ 4.8), and enzyme solution was added at 100: $1(\mathrm{v} / \mathrm{v})$, and reacted at $30{ }^{\circ} \mathrm{C}$ for $3 \mathrm{~h}$. The product was detected by thin-layer chromatography (Jo et al. 2003; Qin et al. 2011).

\section{Detection and identification of proteins by tandem time-of-flight mass spectrometry}

Purified enzymes were identified by tandem time-offlight mass spectrometry: The enzyme samples were first subjected to SDS-PAGE, and the $\beta$-glucosidase band was cut out, followed by subjecting to tandem time-of-flight mass spectrometry. The fingerprints of peptide fragments were obtained after scanning analysis by timeof-flight mass spectrometry (4800 Proteomics Analyzer, Applied Biosystems, USA), and the data was analyzed by using the Mascot software to query and identify purified enzymes on the SWISS-PROT database (Scheibner et al. 2008; Lee et al. 2007).

\section{Enzymatic properties of purified enzyme The effect of temperature on the enzyme activity and stability of $\beta$-glucosidase}

The definition of relative enzyme activity: the highest enzyme activity under a certain condition of the experimental project was set to $100 \%$, and the ratio of enzyme 
activity under other conditions to the highest enzyme activity was defined as relative enzyme activity.

To determine the optimal temperature of endoglucanase and $\beta$-glucosidase, their enzyme activity was measured under the conditions of $30{ }^{\circ} \mathrm{C}-90{ }^{\circ} \mathrm{C}$ in $50 \mathrm{mM}$ acetate buffer of.

To determine the effect of temperature on the stability of $\beta$-glucosidase, the enzyme was incubated in a water bath at temperatures between $40{ }^{\circ} \mathrm{C}$ and $90{ }^{\circ} \mathrm{C}$ with a gradient of $5{ }^{\circ} \mathrm{C}$. The enzymes were incubated at each temperature for $60 \mathrm{~min}$, and the residual enzyme activity was then measured at $60{ }^{\circ} \mathrm{C}$.

\section{The impact of pH on the enzyme activity and stability of $\beta$-glucosidase}

To determine the effect of $\mathrm{pH}$ on enzyme activity of $\beta$-glucosidase, the following four solutions with a concentration of $50 \mathrm{mM}$ were used: disodium hydrogen phosphate-citric acid buffer, $\mathrm{pH}$ 2.6-7.5; Tris- $\mathrm{HCl}$ buffer, pH7.5-pH 9.0; glycine-NaOH buffer, $\mathrm{pH}$ 9.0-11.0.

Under the temperature condition where the enzyme is stable, the enzyme was mixed with the buffer with a $\mathrm{pH}$ value ranging between 3.0 and 9.0, and the relative enzyme activities and the optimal $\mathrm{pH}$ value of endoglucanase and $\beta$-glucosidase were determined.

The enzyme was further stored in a solution with a $\mathrm{pH}$ value between 3.0 and 11.0. After being left at $4{ }^{\circ} \mathrm{C}$ for 24 h, it was kept at $30{ }^{\circ} \mathrm{C}$ for 3 hours. The relative enzyme activities of endoglucanase and $\beta$-glucosidase were determined at the optimum $\mathrm{pH}$ and temperature.

\section{Effect of metal ions on $\beta$-glucosidase activity}

Different metal ions were added to the purified enzyme solution with a final concentration of $2 \mathrm{mM}$, and the enzyme activity was then tested. The enzyme activity was calculated according to the average value of data from three parallel experiments.

\section{Kinetics analysis of the purified $\beta$-glucosidase}

To determine the kinetic parameters of the enzymatic reaction of $\beta$-glucosidase, pNPG was used as the substrate and the reaction was performed under $\mathrm{pH} 4.8$ at $30{ }^{\circ} \mathrm{C}$. The initial reaction rate was calculated, and the $K_{\mathrm{m}}$ value and $V_{\max }$ of the purified $\beta$-glucosidase was calculated by using double reciprocal plotting method (Lineweaver-Burk plot (Lineweaver and Burk 1934).

\section{Results}

Purification and characterization of $\beta$-glucosidase from $F$. chlamydosporum HML278 fermented solution

It was shown that the enzyme activity of $\beta$-glucosidase reached a maximum of $115.2 \mathrm{U} / \mathrm{g}$ after 4 days of solid bagasse culture of F. chlamydosporium HML278. To purify the enzymes from fermented solution of $F$ chlamydosporium HML278, an anion exchange column was initially utilized, but the separation effect was not promising and there was no obvious protein peak, it was speculated that the isoelectric point may be too high. A total of $115.2 \mathrm{U}(20 \mathrm{~mL})$ of crude enzyme solution was further subjected to non-denaturing gel electrophoresis without adding a comb in order to increase the sample load. The active gel was recovered, and subjected to gel filtration chromatography. The enzyme BG FH1was obtained after about $48 \mathrm{~min}$, and BG FH2 was obtained about 64 min after running (Fig. 1). SDS-PAGE analysis showed that the molecular weights of BG FH1and BG FH2 were $93 \mathrm{kDa}$ and $52 \mathrm{kDa}$, respectively (Fig. 2), and the recovery rate of enzymes for purification was $4.0 \%$ and $20.0 \%$, respectively. The fold-purification of BG FH1 and BG FH2 was 14.0 and 28.8 (Table 1), respectively,and the enzyme activity for each enzyme was $5.6 \mathrm{U} / \mathrm{mg}$ and $11.5 \mathrm{U} / \mathrm{mg}$, respectively. The zymography analysis of non-denaturing electrophoresis confirmed that the strain produced two different $\beta$-glucosidases, and both enzymes are a single subunit protein (Fig. 3).

Some other peptide sequences were detected by tandem time-of-flight mass spectrometry, but there was not any enzyme information in the protein database, thus these protein sequences were not identified.

\section{The hydrolysis activity of BG FH1 and BG FH2}

The thin-layer chromatography experiment showed that both BG FH1 and BG FH2 had hydrolytic activity, and can hydrolyze cellobiose to generate glucose. In addition, the enzymes also showed transglycoside activity and can synthesize cellotriose and cellotetraose using glucose (Fig. 4).

High performance liquid chromatography analysis showed that BG FH1 hydrolyzed cellobiose (retention time, $10.72 \mathrm{~min}$ ) to obtain glucose (retention time $7.36 \mathrm{~min}$ ), which can be further used as a substrate to synthesize cellotriose (retention time $12.46 \mathrm{~min}$ ) (Fig. 5). The BG FH1 also had transglycoside activity, which was similar to $\beta$-glucosidase produced from other strains (Kaya et al. 2008; Seidle et al. 2006; Seidle and Huber 2005).

\section{The properities of $\beta$-glucosidase isolated from $F$. chlamydosporum HML278} Optimum temperature and thermal stability of $\beta$-glucosidase Our results showed that the optimum temperature of $\beta$-glucosidases BG FH1 and BG FH2 from $F$. chlamydosporium HML278 was $60{ }^{\circ} \mathrm{C}$ at $\mathrm{pH}$ 5.0. The $\beta$-glucosidase exhibited good stability at temperature below $70{ }^{\circ} \mathrm{C}$, and the enzyme retained $75 \%$ of the enzyme activity when incubated at $70{ }^{\circ} \mathrm{C}$ for 1 hour (Fig. 6). Enzymes that are 


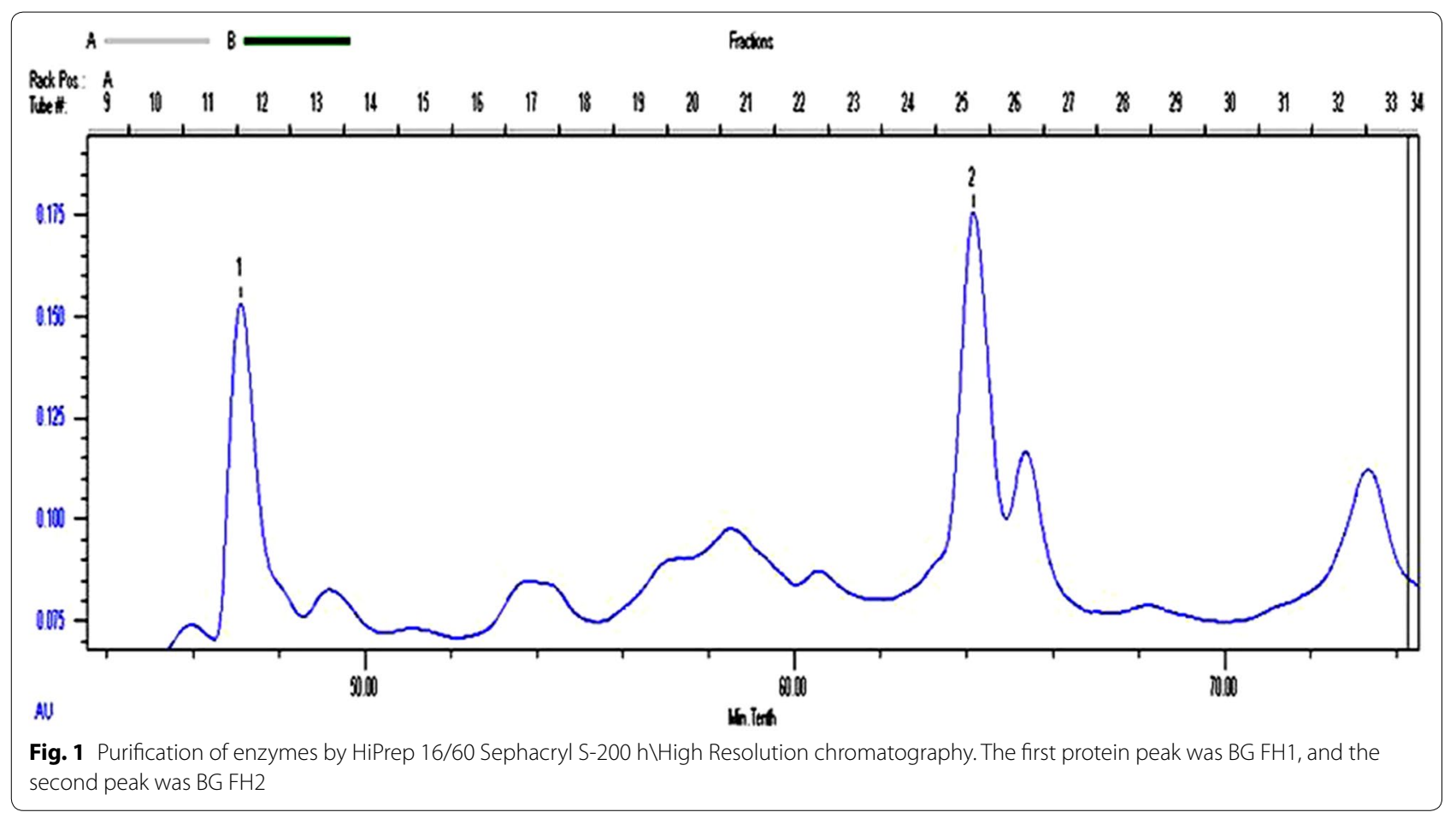

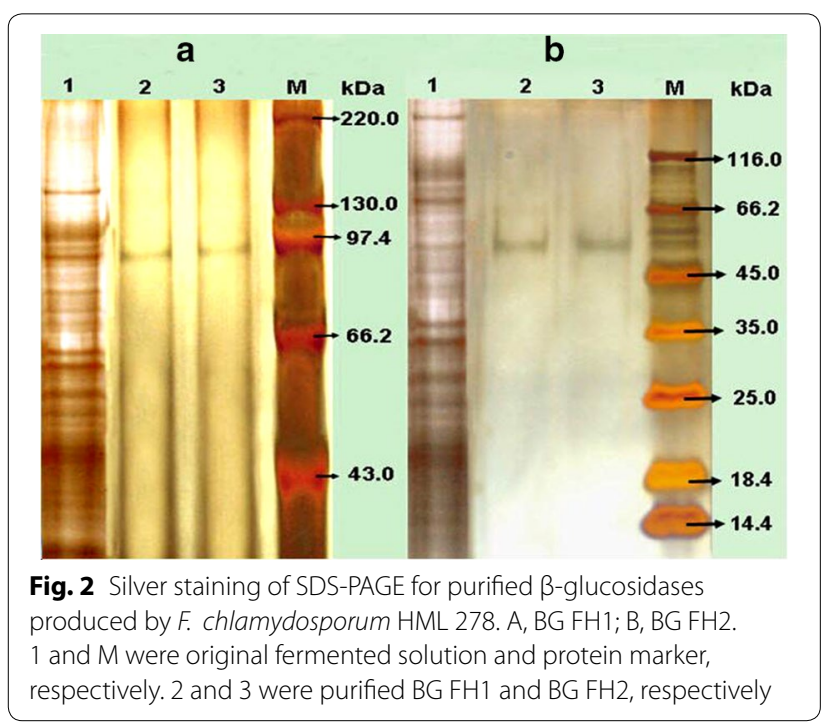

stable at temperatures above $60{ }^{\circ} \mathrm{C}$ are defined as heatresistant enzymes, and these enzymes play an important role in the production of alcohol by enzymatic saccharification and fermentation of biomass materials (Alani et al. 2008). It has been shown that Fusarium species can produce heat-resistant cellulase (Quarantin et al. 2019; Christakopoulos et al. 1995; Kumar et al. 1991; Christakopoulos et al. 1989; Matsumoto et al. 1974; Wood 1969). Our previous study demonstratedthat $F$.

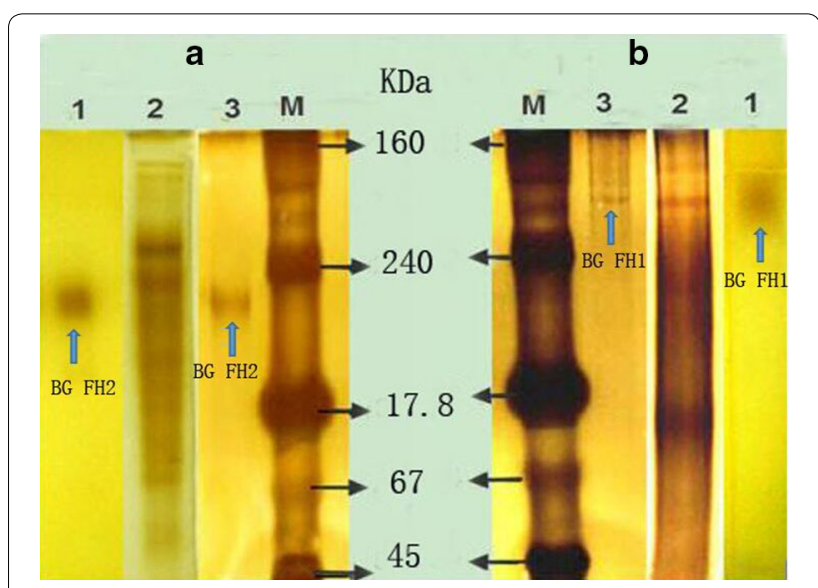

Fig. 3 Zymogram analysis of $\beta$-glucosidases produced by $F$. chlamydosporum HML 278. A, BG FH2; B, BG FH1, respectively. Lane 1 and 3 were purified enzymes, respectively. land 2 was the original fermented solution. lane $M$ was the Serva native-PAGE protein marker (SERVA Electrophoresis GmbH, Germany): The arrows pointed to the location of the corresponding enzymes. lane 1 was stained for $\beta$-glucosidase activity using $0.03 \% \mathrm{FeCl}_{3}$ and $0.1 \%$ esculoside; lanes 2, 3 , and $M$ were silver stained

chlamydosporium can produce heat-resistant cellulase (Qin et al. 2010).

Chan et al. purified $\beta$-glucosidase DT-Bgl and showed that the enzyme exhibited the maxium activity at $70{ }^{\circ} \mathrm{C}$. After hydrolysis of substrate to glucose, which 
Table 1 Summary of purification of $\beta$-glucosidases produced by F. chlamydosporum HML 278

\begin{tabular}{|c|c|c|c|c|c|}
\hline Purification step & Total activity (U) & Total protein (mg) & $\begin{array}{l}\text { Specific activity (U/ } \\
\text { mg) }\end{array}$ & $\begin{array}{l}\text { Purification fold Yield } \\
\text { (\%) }\end{array}$ & $\begin{array}{l}\text { Purification } \\
\text { fold }\end{array}$ \\
\hline Crude enzyme & 115.2 & 282.0 & 0.4 & 100.0 & 1.0 \\
\hline Native Page & 45.6 & 14.8 & 3.1 & 39.6 & 7.8 \\
\hline \multicolumn{6}{|c|}{ Gel filtration chromatographic } \\
\hline BG FG1 & 4.5 & 0.8 & 5.6 & 4.0 & 14.0 \\
\hline BG FG2 & 21.8 & 1.9 & 11.5 & 20.0 & 28.8 \\
\hline
\end{tabular}

Activities were measured on CMC

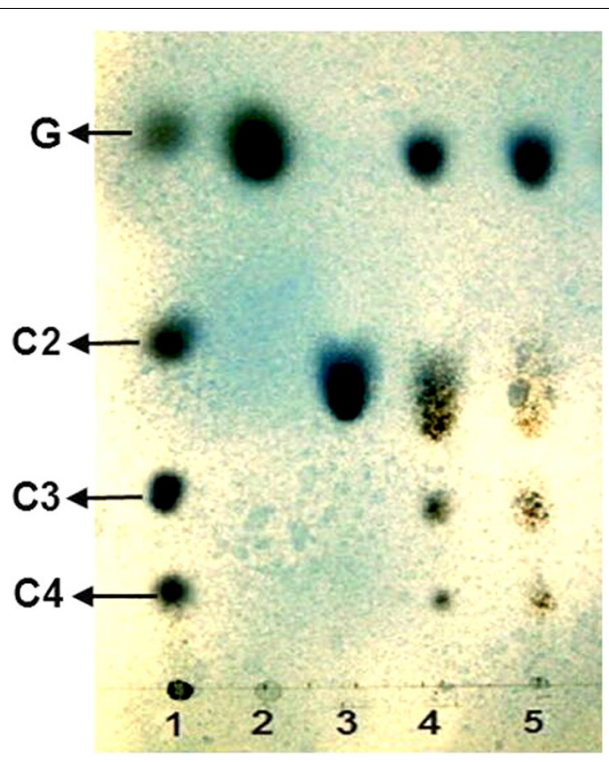

Fig. 4 Hydrolysis property and transglycosylation activity of the purified $\beta$-glucosidases from F. chlamydosporum HML 278, as demonstrated by thin layer chromatography. Lane 1, mixed standards containing G Glucose, C2 Cellobiose, C3 Cellotriose, and C4 Cellotetraose; Lane 2, Glucose standard; Lane 3, Cellobiose standard; Lane 4, Cellobiose + BGFH1; Lane 5, Cellobiose + BG FH2

can be further fermented to produce ethanol (Chan et al. 2016). Liew et al. purified a new $\beta$-glucosidase BglD5 (GH1) from Jeotgalibacillus malaysiensis, and BglD5 was stable at temperature below $65{ }^{\circ} \mathrm{C}$, which promoted the cellulase hydrolysis (Liew et al. 2018). Kumar found that endoglucanase and $\beta$-glucosidase retained enzymatic activity within 60 minutes at $80^{\circ} \mathrm{C}$. These high-temperature enzymes are suitable for application in cellulosic ethanol production (Kumar et al. 1991). Tiwari et al. found that $\beta$-glucosidase RA10 from Bacillus subtilis was stable at $80{ }^{\circ} \mathrm{C}$. The heat-stable $\beta$-glucosidase enhanced saccharification efficiency and thus released much higher level of glucose than previous reports. This enzyme can enhance

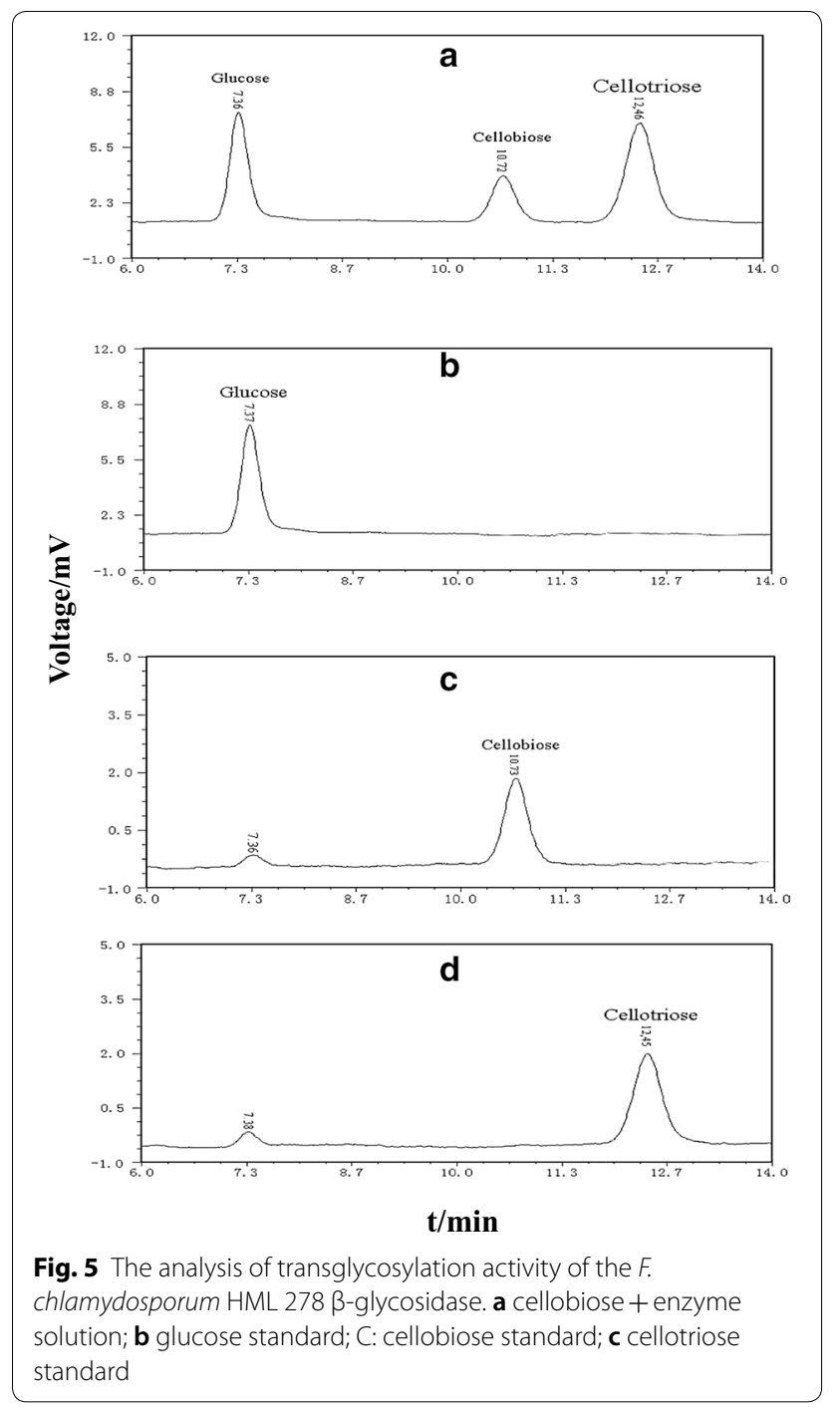

the efficiency of hydrolysis and hydrolyze the substance of cellulose into fermentable sugar (Tiwari et al. 2017). Xia et al. found that the cellulase with good thermal stability (stable at $60{ }^{\circ} \mathrm{C}$ ) can significantly improve the saccharification efficiency of cellulose hydrolysis (Xia et al. 2016). 


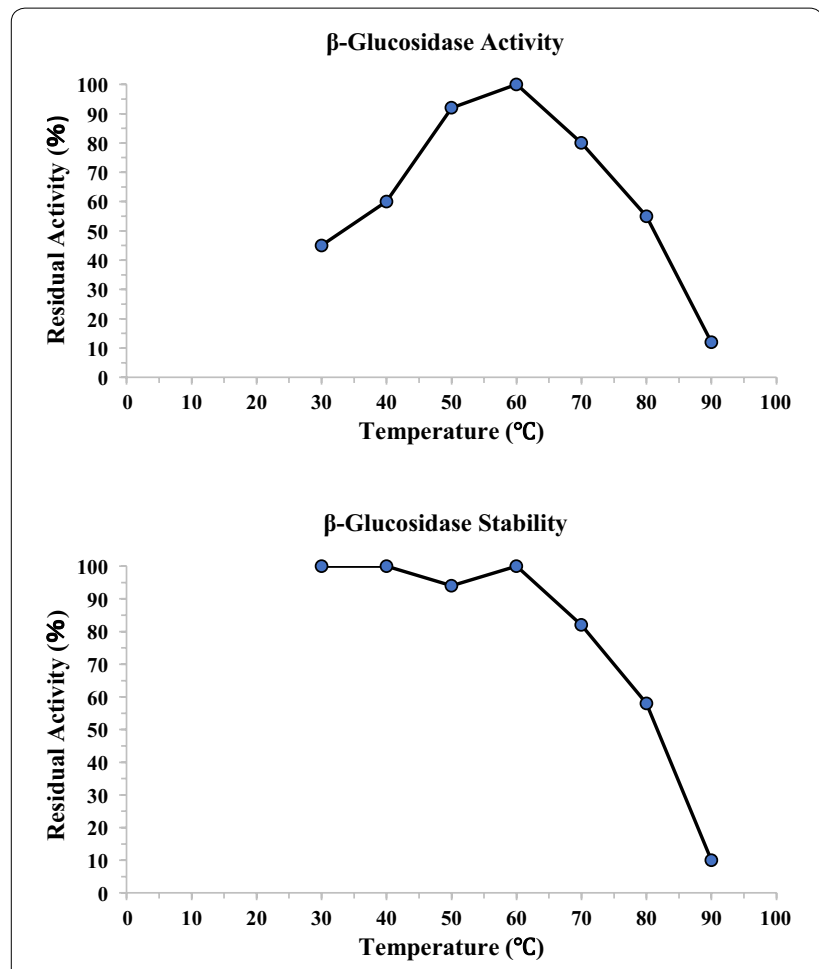

Fig. 6 Analysis of the optimum temperature and thermal stability of the $\beta$-Glucosidase from F.chlamydosporum HML 278

Thermophilic fungi can produce heat-stable enzymes. It is of note that cellulose swells at high temperature, which makes it easier to break down. Thus, high temperature can promote the penetration of enzymes into materials and result in a better degradation. The screening of thermophilic fungi and the application of heat-resistant enzymes are important research directions for comprehensive applications of cellulose (Moretti et al. 2012a, b; de Cassia Pereira et al. 2015).

\section{The optium $\mathrm{pH}$ and stability of purified $\beta$-glucosidase at different $\mathrm{pH}$ conditions}

The $\beta$-glucosidases produced by $F$. chlamydosporum HML278 were relatively stable in the $\mathrm{pH}$ ranging from 4.0 to 10.0 , and showed maximum activity at $\mathrm{pH} 5.0$ (Fig. 7). Christakopoulos et al. screened a strain of Fusarium oxysporum and which had an optimum $\mathrm{pH}$ of 4.5 (Christakopoulos et al. 1995). Matsumoto et al. screened a Fusarium moniliforme strain and the $\beta$-glucosidase produced by this strain was stable at $\mathrm{pH}$ between 4.0 and 11.0. The enzymes with a wide $\mathrm{pH}$ tolerance range usually have broader applications (Matsumoto et al. 1974). Since $F$. chlamydosporum has a wide $\mathrm{pH}$ tolerance range, it may have greater application potential (Christakopoulos et al. 1995; Christakopoulos et al. 1989; Matsumoto et al. 1974; Wood 1969).

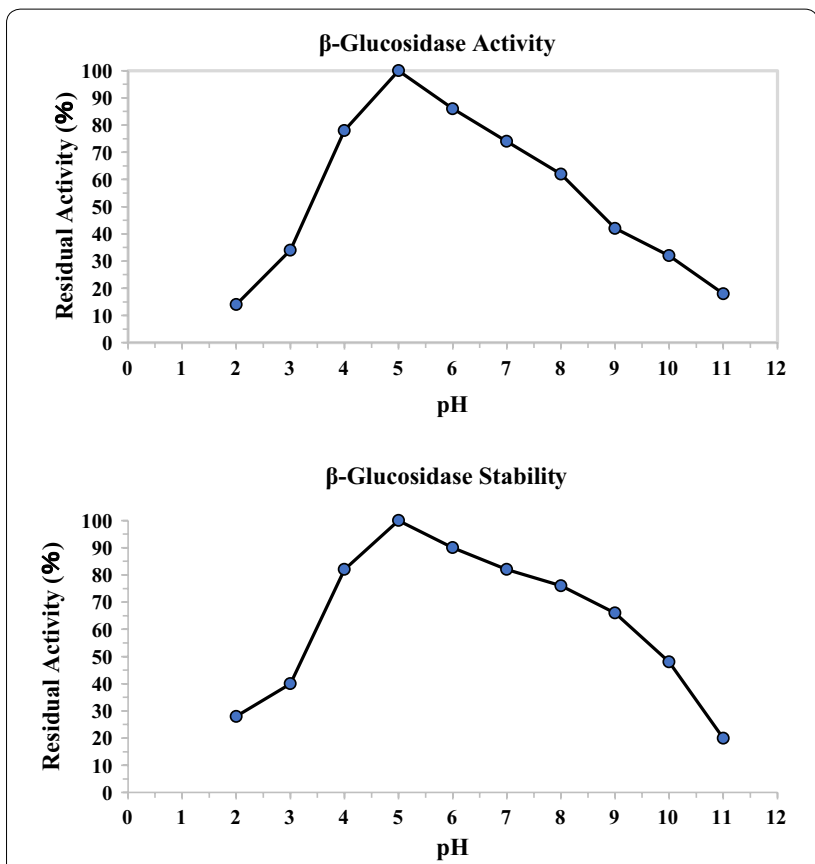

Fig. 7 The optimum $\mathrm{pH}$ and effect of $\mathrm{pH}$ on the activity and stability of the $\beta$-Glucosidase from F.chlamydosporum HML 278

\section{Effect of metal ions on the $\beta$-glucosidase purified from $F$. chlamydosporum HML278}

Metal ions are often used as activators or inhibitors in the catalytic reaction of enzymes (Grasso et al. 2012). Therefore, adding appropriate metal ions to the enzyme reaction system can improve the catalytic efficiency of the enzyme.

It was shown that $\mathrm{Ag}^{+}, \mathrm{Co}^{2+}, \mathrm{Cu}^{2+}, \mathrm{Zn}^{2+}$, and $\mathrm{Hg}^{2+}$ strongly inhibited the $\beta$-glucosidase purified from $F$. chlamydosporum HML278. In contrast, $\mathrm{Mn}^{2+}, \mathrm{Ca}^{2+}, \mathrm{Mg}^{2+}$, and $\mathrm{Fe}^{3+}$ significantly activated enzyme, whereas $\mathrm{Zn}^{2+}$ and $\mathrm{Ni}^{2+}$ had no obvious effect on the enzyme activity (Table 2).

It was observed that all divalent metal ions had effects on the enzyme activity. The bivalent ions $\mathrm{Hg}^{2+}$ and $\mathrm{Co}^{2+}$ completely inhibited enzyme activity. $\mathrm{Hg}^{2+}$ can interact with cysteine residues in sulfhydryl bonds (Stricks and Kolthoff 1953). It reacts with cysteine residues, especially in -SH group, and can change the tertiary structure of the protein (Lee et al. 2018). It was speculated that the active site may contain sulfhydryl groups, and these sulfhydryl groups participate in the catalysis and are essential for maintaining the structure of the enzyme (Joo et al. 2009).

The divalent cobalt ion forms a complex with various amino acids, and binding of the cobalt ion to active site of the enzyme is irreversible, completely inhibiting the activity of the enzyme. Other ions, such as $\mathrm{Mg}^{2+}$, $\mathrm{Mn}^{2+}, \mathrm{Ca}^{2+}, \mathrm{Na}^{+}, \mathrm{Cu}^{2+}$, and $\mathrm{Fe}^{3+}$ also tend to form metal 
Table 2 Effect of various metal ions and inhibitors on HML278 $\beta$-glucosidase activity

\begin{tabular}{llc}
\hline Metal ions and inhibitors & \multicolumn{2}{l}{$\begin{array}{l}\text { Relative } \beta \text {-glucosidase } \\
\text { activity (\%) }\end{array}$} \\
\cline { 2 - 3 } $\mathbf{1 0} \mathbf{~ m M}$ & BG FG1 & BG FG2 \\
\hline Control (Crude) & 100 & 100 \\
$\mathrm{Mn}^{2+}$ & 258.6 & 234.6 \\
$\mathrm{Mg}^{2+}$ & 186.4 & 176.4 \\
$\mathrm{Ca}^{2+}$ & 159.8 & 148.2 \\
$\mathrm{Zn}^{2+}$ & 102.4 & 98.8 \\
$\mathrm{Ni}^{+}$ & 92.6 & 96.2 \\
$\mathrm{Cu}^{2+}$ & 64.6 & 54.5 \\
$\mathrm{Ag}^{2+}$ & 56.2 & 43.4 \\
$\mathrm{Co}^{2+}$ & 48.2 & 38.2 \\
$\mathrm{Hg}^{2+}$ & 40.8 & 30.2 \\
\hline
\end{tabular}

Values represent the means of values from three independent experiments, with a standard deviation

complexes with proteins, which ultimately affect enzyme activity by changing protein structure (Shrivastava et al. 2017).

Feng et al. reported that $\mathrm{Ca}^{2+}$ increased $\beta$-glucosidase Bgl3A activity by $20 \%$ (Feng et al. 2015). Xie et al. reported that $\mathrm{Ca}^{2+}$ at a concentration of $5 \mathrm{mM}$ increased $\beta$-glucosidase activity by $58 \%$ (Xie et al. 2015). It has been reported that $\mathrm{Ca}^{2+}$ and $\mathrm{Mg}^{2+}$ can bind to enzymes to form a stable conformation and improve the catalytic effect (Oyekola et al. 2007).

\section{Kinetic experiment of $\beta$-glucosidase purified from $F$. chlamydosporum HML278}

By using pNPG as a substrate, it was shown that the $K_{\mathrm{m}}$ and $V_{\max }$ values of $\beta$-glucosidase were $2.76 \mathrm{mg} / \mathrm{mL}$ and $20.6 \mathrm{U} / \mathrm{mg}$, respectively.

\section{Discussion}

This study reported that F. chlamydosporum HML278 can utilize sugarcane bagasse as carbon source for solid-state fermentation to produce heat-resistant $\beta$-glucosidase. By employing non-denaturing gel recovery and gel filtration chromatography, two $\beta$-glucosidase BG FH1 and BG FH2 were purified, with molecular weights of $93 \mathrm{kDa}$ and $52 \mathrm{kDa}$, respectively. Purified BG FH1 and BG FH2 were $\beta$-glucosidase enzymes with high transglycosidic activity. Thin-layer chromatography and high-performance liquid chromatography analysis showed that BG FH1 and BG FH2 had hydrolytic activity and hydrolyzed cellobiose to glucose. Moreover, the enzymes also had transglycosidic activity and can synthesize cellobiose and cellotriose using low molecular weight monosaccharides.
The optimum temperature for purified BG FH1 and BG FH2 from $F$. chlamydosporum HML278 was $60{ }^{\circ} \mathrm{C}$, and the enzymes were stable below $70{ }^{\circ} \mathrm{C}$. The enzymes had the highest activity at $\mathrm{pH} 6.0$, and were stable in the $\mathrm{pH}$ ranging from $\mathrm{pH} 4.0$ to $\mathrm{pH} 10.0 . \mathrm{Ag}^{+}, \mathrm{Co}^{2+}$, $\mathrm{Cu}^{2+}, \mathrm{Zn}^{2+}$, and $\mathrm{Hg}^{2+}$ had strong inhibitory effect on the purified enzymes, while $\mathrm{Mn}^{2+}, \mathrm{Ca}^{2+}, \mathrm{Mg}^{2+}$, and $\mathrm{Fe}^{3+}$ had obvious activation effect on the enzymes, and $\mathrm{Zn}^{2+}$ and $\mathrm{Ni}^{2+}$ had no obvious effects on enzymes. In addition, some peptide sequences were also identified by tandem time-of-flight mass spectrometry, but there was no relative information on these peptides in the protein database.

$\beta$-glucosidase is a key enzyme that is involved in cellulolytic enzyme-mediated hydrolysis. The presence of sufficient $\beta$-glucosidases can also improve the saccharification efficiency of cellulose (Teugjas and Väljamäe 2013; Prawitwong et al. 2013; Ng et al. 2011).

Heat-stable enzymes have obvious advantages as catalysts. Because high temperature can promote the enzyme penetration and cell wall destruction during the process (Kwon et al. 1994), the hydrolysis effect is usually better. Thermophilic fungi are now considered as a promising source for producing thermostable cellulase that used for cellulose degradation, and can increase the saccharification rate (de Cassia Pereira et al. 2015).

By using nuclear magnetic resonance analysis, Makropoulou et al. found that $\beta$-glucosidase from Fusarium oxysporum had transglycosidic activity. It can catalyze a variety of disaccharides to generate $\beta$-D-glucose through transglycosidation. Fusarium oxysporum can directly hydrolyze cellulose and synthesize ethanol, glycol, and glycerol after saccharification. Because $\beta$-glucosidase has transglycosidic activity, ethanol alcohol is preferentially synthesized (Makropoulou et al. 1998). The cellulase produced by Fusarium spp. is heat-resistant. It has been reported that Fusarium spp. can also produce enzymes involved in alcohol production, which can saccharify cellulose materials while convert the five- or six-carbon sugars into alcohol (Brunner and Lichtenauer 2007; Gómez-Gómez et al. 2001; Maheshwari et al. 2000; Royer and Moyer 1995; Kumar et al. 1991; Singh and Kumar 1991; Vaidy and Seeta 1984; Wood and McCrae 1977; Sampathnarayanan and Shanmugasundaram 1970). In conclusion, we characterized two $\beta$-glucosidases with both hydrolytic and transglycoside activities from $F$. chlamydosporum HML278 fermentation, and these identified enzymes have great potential in industrial application, such as bioethanol, papermaking, feed, food, textile, detergent, and pharmaceutical industries (Xie et al. 2015; Kim et al. 2011; Alani et al. 2008; Maheshwari et al. 2000). 


\section{Acknowledgements}

The authors would like to acknowledge Guangxi Colleges Universities Key Laboratory of Exploitation and Utilization of Microbial and Botanical Resources for supporting our study.

\section{Authors' contributions}

YLQ and HYH conceived and designed the research. YLQ wrote the paper. $Y L Q, Q Q L$ and YF conducted the experiments. YLQ and FFL analyzed data. All authors read and approved the final manuscript.

\section{Funding}

This study was supported by National Natural Science Foundation of China (No. 31660017).

\section{Availability of data and materials}

All data generated or analysed during this study are included in this published article.

\section{Ethics approval and consent to participate}

This work did not involve the direct study of humans. All applicable international, national, and/or institutional guidelines for the care and use of animals were followed and all. This article does not contain any studies with human participants or animals performed by any of the authors.

\section{Consent for publication}

The authors confirm that the work described has not been published before, that it is not under consideration for publication elsewhere, that its publication has been approved by all co-authors. The authors agree to publication in the Journal of AMB Express.

\section{Competing interest}

The authors declare that they have no conflict of interest.

\section{Author details}

${ }^{1}$ College of Chemistry and Biological Engineering, Hechi University, 546300 Yizhou, China. ${ }^{2}$ Guangxi Colleges Universities Key Laboratory of Exploitation and Utilization of Microbial and Botanical Resources, 546300 Yizhou, China.

Received: 27 June 2020 Accepted: 24 September 2020 Published online: 08 October 2020

\section{References}

Alani F, Anderson WA, Moo-Young M (2008) New isolate of Streptomyces sp. with novel thermoalkalotolerant cellulases. Biotechnol Lett 30:123-126. https://doi.org/10.1007/s10529-007-9500-9

Arantes V, Saddler JN (2010) Access to cellulose limits the efficiency of enzymatic hydrolysis: the role of amorphogenesis. Biotechnol Biofuels 3, 4. https://doi.org/10.1186/1754-6834-3-4

Bayer EA, Lamed R, White BA, Flint HJ (2008) From cellulosome to cellulosomics. Chem Rec 8:364-377. https://doi.org/10.1002/tcr.20160

Bradford MM (1976) A rapid and sensitive method for the quantitation of microgram quantities of protein utilizing the principle of proteindye binding. Anal Biochem 7:248-254. https://doi.org/10.1006/ abio.1976.9999

Brunner K, Lichtenauer AM, Kratochwill K, Delic M, Mach RL (2007) Xyr1 regulates xylanase but not cellulase formation in the head blight fungus Fusarium graminearum. Curr Genet 52:213-220. https://doi.org/10.1007/ s00294-007-0154-x

Chan CS, Sin LL, Chan KG, Shamsir MS, Manan FA, Sani RK, Goh KM (2016) Characterization of a glucose-tolerant $\beta$-glucosidase from Anoxybacillus sp. DT3-1. Biotechnol Biofuels 9:174

Chauve M, Mathis H, Huc D, Casanave D, Monot F, Lopes Ferreira N (2010) Comparative kinetic analysis of two fungal $\beta$-glucosidases. Biotechnol Biofuels 3: 3.https://doi.org/10.1186/1754-6834-3-3

Christakopoulos P, Kekos D, Macris BJ, Claeyssens M, Bhat MK (1995) Purification and characterization of a less randomly acting
endo-1,4-beta-D-glucanase from the culture filtrates of Fusarium oxysporum. Arch Biochem Biophys 316(1):428-433. https://doi.org/10.1006/ abbi.1995.1057

Christakopoulos P, Macris BJ, Kekos D (1989) Direct fermentation of cellulose to ethanol by Fusarium oxysporum. Enzyme Microb Technol 11(4):236-239. https://doi.org/10.1016/0141-0229(89)90098-7

de Cassia Pereira J, Paganini Marques N, Rodriques A, Brito de Oliveira T, Boscolo M, da Silva R, Gomes E, Bocchini Martins DA (2015) Thermophilic fungi as new sources for production of cellulases and xylanases with potential use in sugarcane bagasse saccharification. J Appl Microbiol 118:928-939. https://doi.org/10.1111/jam.12757

Fan LH, Zhang ZJ, Mei S, Lu YY, Li M, Wang ZY, Yang JG, Yang ST, Tan TW (2016) Engineering yeast with bifunctional minicellulosome and cellodextrin pathway for coutilization of cellulose-mixed sugars. Biotechnol Biofuels 9:137. https://doi.org/10.1186/s13068-016-0554-6.eCollection

Feng T, Liu H, Xu Q, Sun J, Shi H (2015) Identification and characterization of two endogenous $\beta$-glucosidases from the termite Coptotermes formosanus. Appl Biochem Biotechnol 176(7):2039-2052. https://doi. org/10.1007/s12010-015-1699-7

Gomes DG, Serna-Loaiza S, Cardona CA, Gama M, Domingues L (2018) Insights into theeconomic viability of cellulases recycling on bioethanol production from recycled paper sludge. Bioresour Technol 267:347-355. https:// doi.org/10.1016/j.biortech.2018.07.056

Gómez-Gómez E, Isabel M, Roncero G, Di Pietro A, Hera C (2001) Molecular characterization of a novel endo-beta-1,4-xylanase gene from the vascular wilt fungus Fusarium oxysporum. Curr Genet 40(4): 268-275. https:// doi.org/10.1007/s00294-001-0260-0

Grasso G, Salomone F, Tundo GR, Pappalardo G, Ciaccio C, Spoto G, Pietropaolo A, Coletta M (2012) Metal ions affect insulin-degrading enzyme activity. J Inorg Biochem 117:351-358. https://doi.org/10.1016/j.jinor gbio.2012.06.010

Han Y, Chen H (2008) Characterization of $\beta$-glucosidase from corn stover and its application in simultaneous saccharification and fermentation. Bioresour Technol 99:6081-6087. https://doi.org/10.1016/j.biort ech.2007.12.050

Haven MO, Jørgensen H (2013) Adsorption of $\beta$-glucosidases in two commercial preparations onto pretreated biomass and lignin. Biotechnol Biofuels 6:165. https://doi.org/10.1186/1754-6834-6-165

Ikeda Y, Park EY, Okida N (2006) Bioconversion of waste office paper to gluconic acid in a turbine blade reactor by the filamentous fungus Aspergillus niger. Bioresour Technol 97:1030-1035. https://doi.org/10.1016/j.biort ech.2005.04.040

Joo AR, Jeya M, Lee KM, Sim WI, Kim JS, Kim IW, Kim YS, Oh DK, Gunasekaran P, Lee JK (2009) Purification and characterization of a $\beta$-1, 4-glucosidase from a newly isolated strain of Fomitopsis pinicola. Appl Microbiol Biotechnol 83:285-294. https://doi.org/10.1007/s00253-009-1861-7

Jo YY, Jo KJ, Jin YL, Kim KY, Shim JH, Kim YW, Park RD (2003) Characterization and kinetics of $45 \mathrm{kDa}$ chitosanase from Bacillus sp. P16. Biosci Biotechnol Biochem 67:1875-1882. https://doi.org/10.1271/bbb.67.1875

Kamila PB, Piotr P, Halina K, Kazimierz P, Marta K, Marcin D (2016) Evaluation of pine kraft cellulosic pulps and fines from papermaking as potential feedstocks for biofuel production. Cellulose 23:649-659. https://doi. org/10.1007/s10570-015-0808-7

Kaya M, Ito J, Kotaka A, Matsumura K, Bando H, Sahara H, Ogino C, Shibasaki S, Kuroda K, Ueda M, Kondo A, Hata Y (2008) Isoflavone aglycones production from isoflavone glycosides by display of beta-glucosidase from Aspergillus oryzae on yeast cell surface. Appl Microbiol Biotechnol 79(1): 51-60. https://doi.org/10.1007/s00253-008-1393-6

Kim YS, Yeom SJ, Oh DK (2011) Characterization of a GH3 family beta-glucosidase from Dictyoglomus turgidum and its application to the hydrolysis of isoflavone glycosides in spent coffee grounds. J Agric Food Chem 59(21):11812-11818. https://doi.org/10.1021/jf2025192

Kovacs K, Macrelli S, Szakacs G, Zacchi G (2009) Enzymatic hydrolysis of steam-pretreated lignocellulosic materials with Trichoderma atroviride enzymes produced in-house. Biotechnol Biofuels 2:14. https://doi. org/10.1186/1754-6834-2-14

Kumar PKR, Singh A, Schuegerl K (1991) Fed-batch culture for the direct conversion of cellulosic substrates to acetic acid/ethanol by Fusarium oxysporum. Process Biochem 26(4):209-216. https://doi.org/10.1016/00329592(91)85002-6 
Kwon KS, Lee J, Kang HG, Hah YC (1994) Detection of $\beta$-Glucosidase Activity Polyacrylamide Gels with Esculin as Substrate. Appl Environ Microbiol 12: 4584-4586

Laemmli UK (1970) Cleavage of structural proteins during the assembly of the head of bacteriophage T4. Nature 227:680-685. https://doi. org/10.1038/227680a0

Lee C, O'Neill MA, Tsumuraya Y, Darvill AG, Ye ZH (2007) The irregular xylem9 mutant is deficient in xylan xylosyltransferase activity. Plant Cell Physiol 48(11):1624-1134. https://doi.org/10.1093/pcp/pcm135

Lee HJ, Lee YS, Choi YL(2018) Cloning, purification, and characterization of an organic solvent-tolerant chitinase, MtCh509, from Microbulbifer thermotolerans DAU221. Biotechnol Biofuels 11:303. https://doi.org/10.1186/ s13068-018-1299-1

Liew KJ, Lim L, Woo HY, Chan KG, Shamsir MS, Goh KM (2018) Purification and characterization of a novel $\mathrm{GH} 1$ beta-glucosidase from Jeotgalibacillus malaysiensis. Int J Biol Macromol 115:1094-1102. https://doi. org/10.1016/j.jibiomac.2018.04.156

Lineweaver H, Burk D (1934) The determination of enzyme dissociation constants. J Am Chem Soc 56:658-666. https://doi.org/10.1021/ja01318a036

Maheshwari R, Bharadwaj G, Bhat MK (2000) Thermophilic Fungi: Their Physiology and Enzymes. Microbiol Mol Biol Rev 64:461-488. https://doi. org/10.1128/mmbr.64.3.461-488.2000

Makropoulou M, Christakopoulos P, Tsitsimpikou C, Kekos D, Kolisis FN, Macris BJ. Factors affecting the specificity of beta-glucosidase from Fusarium oxysporum in enzymatic synthesis of alkyl-beta-D-glucosides. Int J Biol Macromol 1998; 22(2):97-101. https://doi.org/1016/ s0141-8130(97)00092-5

Matsumoto K, Endo Y, Tamiya N, Kano M, Miyauchi K (1974) Studies on cellulase produced by the phytopathogens. Purification and enzymatic properties of cellulase of Fusarium moniliforme. J Biochem 76:563-572. https://doi.org/10.1093/oxfordjournals.jbchem.a130600

Miettinen-Oinonen A, Londesborough J, Joutsjoki V, Lantto R, Vehmaanperä J, Ltd. Biotec P (2004) Three cellulases from Melanocarpus albomyces for textile treatment at neutral pH. Enzyme Microb Technol 34:332-341. https://doi.org/10.1016/j.enzmictec.2003.11.011

Moretti MM, Bocchini-Martins DA, Silva RD, Rodrigues A, Sette LD, Gomes E (2012a) Selection of Thermophilic and Thermotolerant Fungi for the Production of Cellulases and Xylanases Under Solid-State Fermentation. Braz J Microbiol 43(3):1062-1071

Moretti MM, Bocchini-Martins DA, Silva RD, Rodrigues A, Sette LD, Gomes E (2012b) Selection of Thermophilic and Thermotolerant Fungi for the Production of Cellulases and Xylanases Under Solid-State Fermentation. Braz J Microbiol 43(3):1062-1071. https://doi.org/10.1590/S1517-83822 0120003000032

Ng IS, Tsai SW, Ju YM, Yu SM, Ho TH (2011) Dynamic synergistic effect on Trichoderma reesei cellulases by novel $\beta$-glucosidases from Taiwanese fungi. Bioresour Technol 102:6073-6081. https://doi.org/10.1016/j.biort ech.2010.12.110

Oyekola OO, Ngesi N, Whiteley CG (2007) Isolation, purification and characterisation of an endoglucanase and $\beta$-glucosidase from an anaerobic sulphidogenic bioreactor. Enzyme Microb Technol 40:637-644. https:// doi.org/10.1016/j.enzmictec.2006.05.020

Pei J, Pang Q, Zhao L, Fan S, Shi H (2012) Thermoanaerobacterium thermosaccharolyticum $\beta$-glucosidase: a glucose-tolerant enzyme with high specific activity for cellobiose. Biotechnol Biofuels 5:31. https://doi. org/10.1186/1754-6834-5-31

Prawitwong P, Waeonukul R, Tachaapaikoon C, Pason P, Ratanakhanokchai K, Deng L, Sermsathanaswadi J, Septiningrum K, Mori Y, Kosugi A (2013) Direct glucose production from lignocellulose using Clostridium thermocellum cultures supplemented with a thermostable $\beta$-glucosidase. Biotechnol Biofuels 6:184. https://doi.org/10.1186/1754-6834-6-184

Qin YL, He HY, Li N, Ling M, Liang ZQ (2010) Isolation of a thermostable cellulase-producing Fusarium chlamydosporum and characterization of the cellulolytic enzymes. World J Microb Biot 26(11):1991-1997. https:// doi.org/10.1007/s11274-010-0383-X

Qin YL, Zhang YK, He HY, Zhu J, Chen GG, Li W, Liang ZQ (2011) Screening and Identification of a Fungal $\beta$-Glucosidase and the Enzymatic Synthesis of Gentiooligosaccharide. Appl Biochem Biotechnol 163:1012-1019. https:// doi.org/10.1007/s12010-010-9105-y

Quarantin A, Castiglioni C, Schäfer W, Favaron F, Sella L (2019) The Fusarium Graminearum Cerato-Platanins Loosen Cellulose Substrates Enhancing
Fungal Cellulase Activity as Expansin-Like Proteins. Plant Physiol Biochem 139:229-238. https://doi.org/10.1016/j.plaphy.2019.03.025

Royer JC, Moyer DL, Reiwitch SG, Madden MS, Jensen EB, Brown SH, Yonker CC, Johnston JA, Golightly EJ, Yoder WT, Shuster JR (1995) Fusarium graminearum $\mathrm{A} 3 / 5$ as a novel host for heterologous protein production. Biotech 13(13):1479-1483. https://doi.org/10.1038/nbt1295-1479

Rubin EM (2008) Genomics of cellulosic biofuels. Nature 454:841-845. https:// doi.org/10.1038/nature07190

Saloheimo M, Nakari-Setälä T, Tenkanen M, Penttilä M (1997) cDNA cloning of a Trichoderma reesei cellulase and demonstration of endoglucanase activity by expression in yeast. Eur J Biochem 24:584-591. https://doi.org/10.111 1/j.1432-1033.1997.00584.x

Sampathnarayanan A, Shanmugasundaram ER (1970) Studies on cellulase of the cotton wilt pathogen Fusarium vasinfectum Atk. Mycopathol Mycol Appl 41(3):223-232. https://doi.org/10.1007/BF02051100

Sánchez OJ, Cardona CA (2008) Trends in biotechnological production of fuel ethanol from different feedstocks. Bioresour Technol 99:5270-5295. https ://doi.org/10.1016/j.biortech.2007.11.013

Scheibner M, Hülsdau B, Zelena K, Nimtz M, de Boer L, Berger RG, Zorn H (2008) Novel peroxidases of Marasmius scorodonius degrade beta-carotene. Appl Microbiol Biotechnol 77:1241-1250. https://doi.org/10.1007/s0025 3-007-1261-9

Seidle HF, Allison SJ, George E, Reuben E, Huber RE (2006) Trp-49 of the family 3 beta-glucosidase from Aspergillus niger is important for its transglucosidic activity: creation of novel beta-glucosidases with low transglucosidic efficiencies. Arch Biochem Biophys 455: 110-118. https://doi. org/10.1016/j.abb.2006.09.016

Seidle HF, Huber RE (2005) Transglucosidic reactions of the Aspergillus niger family 3 beta-glucosidase: qualitative and quantitative analyses and evidence that the transglucosidic rate is independent of $\mathrm{pH}$. Arch Biochem Biophys 436(2):254-264.

Shoemaker SP, Brown RD (1978) Characterization of endo-1,4-beta-Dglucanases purified from Trichoderma virid. Biochim Biophys Acta 523:147-161. https://doi.org/10.1016/0005-2744(78)90017-7

Shrivastava LK, Kumar A, Senger SS, Mishra VN, Panda A (2017) Influence of zypmite on productcivity and nutrient uptake of chickpea (Cicer arietinum) crop under rainfed condition Chhattisgarh plain region. Legume Res 41:95-101. https://doi.org/10.18805/LR-3586

Singh A, Kumar PK (1991) Fusarium oxysporum: status in bioethanol production. Crit Rev Biotechnol 11(2):129-147. https://doi.org/10.3109/07388 559109040619

Stricks W, Kolthoff IM (1953) Reactions between mercuric mercury and cysteine and glutathione. apparent dissociation constants, heats and entropies of formation of various forms of mercuric mercaptocysteine and -glutathione, J Am Chem Soc 75: 5673-5681. https://doi. org/10.1021/ja01118a060

Tanaka T, Hoshina M, Tanabe S, Sakai K, Ohtsubo S, Taniguchi M (2006) Production of D-lactic acid from defatted rice bran by simultaneous saccharification and fermentation. Bioresour Technol 97: 211-217. https://doi. org/10.1016/j.biortech.2005.02.025

Teugjas H, Väljamäe P (2013) Selecting $\beta$-glucosidases to support cellulases in cellulose saccharification. Biotechnol Biofuels 6:105. https://doi. org/10.1186/1754-6834-6-105

Tian S, Luo XL, Yang XS, Zhu JY (2010) Robust cellulosic ethanol produc-tion from SPORL-pretreated lodgepole pine using an adapted strain Saccharomyces cerevisiae without detoxification. Bioresour Technol 101: 8678-8685.

Tiwari R, Singh PK, Singh S, Nain, Pawan KS, Nain, Shukla P (2017) Bioprospecting of novel thermostable $\beta$-glucosidase from Bacillus subtilis RA10 and its application in biomass hydrolysis Biotechnol Biofuels 10:246. https:// doi.org/10.1186/s13068-017-0932-8

Wen Z, Liao W, Chen S (2005) Production of cellulase by Trichoderma reesei from dairy manure. Bioresour Technol 96:491-499. https://doi org/10.1016/j.biortech.2004.05.021

Wood TM (1969) The cellulase of Fusarium solani. Resolution of the enzyme complex. Biochem J 115(3):457-464. https://doi.org/10.1042/bj1 150457

Wood TM, McCrae SI (1977) Cellulase from Fusarium solani: purification and properties of the C1 component. Carbohydr Res 57: 117-133. https://doi. org/10.1016/s0008-6215(00)81925-4

Xia W, Xu XX, Qian LC, Shi PJ, Bai YG, Luo HY, Ma R, Yao B (2016) Engineering a highly active thermophilic $\beta$-glucosidase to enhance its $\mathrm{pH}$ stability 
and saccharification performance. Biotechnol Biofuels 9:147. https://doi. org/10.1186/s13068-016-0560-8

Xie J, Zhao D, Zhao L, Pei J, Xiao W, Ding G, Wang Z (2015) Overexpression and characterization of a $\mathrm{Ca} 2+$ activated thermostable $\beta$-glucosidase with high ginsenoside $\mathrm{Rb} 1$ to ginsenoside $20(\mathrm{~S})$-Rg3 bioconversion productivity. J Ind Microbiol Biotechnol 42:839-850. https://doi.org/10.1007/s1029 5-015-1608-7

Vaidy M, Seeta R, Mishra C, Deshpande V, Rao M (1984) A rapid and simplified procedure for purification of a cellulase from Fusarium lini. Biotechnol Bioeng 26(1):41-45. https://doi.org/10.1002/bit.260260109

Villena MA (2007) $\beta$-glucosidase activity in wine yeasts: application in enology. Enzym Microb Technol 40:420-425. https://doi.org/10.1016/j.enzmi ctec.2006.07.013, Iranzo JFú, Pérez AIB

Zaldivar J, Nielsen J, Olsson L (2001) Fuel ethanol production from lignocellulose: a challenge for metabolic engineering and process integration. Appl Microbiol Biotechnol 56:17-34. https://doi.org/10.1007/s002530100624
Zhang M, Su R, Qi W, He Z (2010) Enhanced enzymatic hydrolysis of lignocellulose by optimizing enzyme complexes. Appl Biochem Biotechnol 160:1407-1414. https://doi.org/10.1007/s12010-009-8602-3

Zhang Z, Liu J, Lan J, Duan C, Ma Q, Feng J (2014) Predominance of Trichoderma and Penicillium in cellulolytic aerobic filamentous fungi from subtropical and tropical forests in China, and their use in finding highly efficient $\beta$-glucosidase. Biotechnol Biofuels 7:107. https://doi. org/10.1186/1754-6834-7-107

\section{Publisher's Note}

Springer Nature remains neutral with regard to jurisdictional claims in published maps and institutional affiliations.

\section{Submit your manuscript to a SpringerOpen ${ }^{\circ}$ journal and benefit from:}

- Convenient online submission

- Rigorous peer review

- Open access: articles freely available online

- High visibility within the field

- Retaining the copyright to your article

Submit your next manuscript at $\boldsymbol{\nabla}$ springeropen.com 